\title{
Sex-specific effects of neonatal progestin receptor antagonism on juvenile social play behavior in rats
}

\author{
R. M. Forbes-Lorman * (D)
}

\begin{abstract}
Developing mammals are exposed to progesterone through several sources; however, the role of progesterone in early development is not well understood. Males express more progestin receptors (PRs) than females within several brain regions during early postnatal life, suggesting that PRs may be important for the organization of the sex differences in the brain and behavior. Indeed, previous studies showed cognitive impairments in male rats treated neonatally with a PR antagonist. In the present study, we examined the role of PRs in organizing juvenile behaviors. Social play behavior and social discrimination were examined in juvenile male and female rats that had been treated with CDB, a PR antagonist, during the first week of postnatal life. Interestingly, neonatal PR antagonism altered different juvenile behaviors in males and females. A transient disruption in PR signaling during development had no effect on social discrimination but increased play initiation and pins in females. These data suggest that PRs play an important role in the organization of sex differences in some social behaviors.
\end{abstract}

Keywords: Rat, Sex differences, Progesterone, Progestin receptor (PR), Social play behavior, Social discrimination

\section{Introduction}

While it is clear that testosterone and its metabolites play an important role in the organization of the male brain and behavior through their actions on androgen receptors and estrogen receptors [1], less is known about the role of progesterone acting upon progestin receptors (PRs) in the developing brain.

Developing mammals are exposed to progesterone, both from fetal and maternal sources (reviewed in [2, 3]). Indeed, male and female rodents have approximately equivalent levels of circulating progesterone during development $[4,5]$. Furthermore, progesterone administration is also commonly used as a contraceptive in lactating women and during pregnancy for prevention of premature birth and (reviewed in [6]).

\footnotetext{
*Correspondence: forbesr@ripon.edu

Department of Biology, Ripon College, 300 W Seward St., Ripon, WI 54971, USA
}

Males express PRs as early as embryonic day 20 in many brain areas [7] and express more PRs than females within several hypothalamic regions on postnatal day (PN)1 but not PN10 [8, 9]. This sex difference in PRs in the developing brain suggests that PRs are important for the organization of the sex differences in the brain. Indeed, blocking PRs using RU-486 during development increases male sex behavior and the expression of ARs in several regions of the adult male brain [10], although another study using a different PR antagonist, ZK 137616, found no effect on male mouse sex behavior [11]. Neonatal PR antagonism using RU-486 also disrupts cognitive ability in adult male rats [12]. It should be noted that RU-498 also binds glucocorticoid receptors, making the role of PRs during development even less clear. CDB-4124 is a PR antagonist with a low binding affinity for glucocorticoid receptors [13] that has been shown to affect forced swim immobility in adult mice [14]. original author(s) and the source, provide a link to the Creative Commons licence, and indicate if changes were made. The images or other third party material in this article are included in the article's Creative Commons licence, unless indicated otherwise in a credit line to the material. If material is not included in the article's Creative Commons licence and your intended use is not permitted by statutory regulation or exceeds the permitted use, you will need to obtain permission directly from the copyright holder. To view a copy of this licence, visit http://creativecommons.org/licenses/by/4.0/. The Creative Commons Public Domain Dedication waiver (http://creativeco mmons.org/publicdomain/zero/1.0/) applies to the data made available in this article, unless otherwise stated in a credit line to the data. 
Several studies have also examined the role of progestins in the organization of social behaviors. For example, neonatal progesterone administration increased play in both sexes [15], while progestin antiserum decreased play only in females [16]. Progesterone has also been demonstrated to play a role in adult male social behaviors. For example, progesterone administration has been found to disrupt social recognition in adult males [17], while a more recent study showed the opposite [18].

In the present study, we examined the organizational role of PRs on juvenile social discrimination and juvenile social play behavior by treating male and female rats with $\mathrm{CDB}$, a specific PR antagonist, during the first week of postnatal life.

\section{Methods and materials}

\section{Subjects and treatment}

Sprague-Dawley rats supplied by Charles River Labs were bred in our animal facility. Animals were housed in standard lab cages with aspen shavings and no enrichment. Dams were checked daily to determine the day of birth and were allowed to deliver normally. Twenty-seven male and 25 female pups were pooled from five different litters and randomly assigned to each treatment group (13 CDB-treated females, 12 oil-treated females, 13 CDB-treated males, and 14 oil-treated males). Each litter contained animals of both sexes and treatment groups and a maximum of three animals from a single litter were assigned to each treatment group. Pups were footmarked with India ink and treated subcutaneously with the $75 \mathrm{~g} / 0.01 \mathrm{~mL} / \mathrm{g}$ body of the PR antagonist CDB- 4124 or vehicle on PNO (day of birth), PN2 and PN4. The vehicle was composed of $0.2 \%$ benzyl alcohol and $0.6 \%$ benzyl benzoate in sesame oil. This treatment regimen is similar to what has been previously used for RU-486 [10]; however, we chose to reduce the number of administrations in order to minimize the injections. We have found that the sesame oil does not clear within a day, so treatment was likely continuous from $\sim$ PN0-PN6. The weight of the pups ranged from 5 to $12 \mathrm{~g}$ over the three days of treatment. CDB-4124 was used because it has a low binding affinity for glucocorticoid receptors [13]. The dose of CDB-4124 is within the range of what has previously had an effect on forced swim immobility in adult mice [14].

All pups remained with dams until weaning at PN21. On PN21, pups were separated into seven cages of six animals and two cages of five animals. In order to minimize litter effects, each cage contained 1-2 animals from each treatment group (i.e., CDB-treated females, CDBtreated males, vehicle-treated females, vehicle-treated males) and approximately half females and half males. An overview timeline of the experiment is shown in Fig. 1. The rats were housed under a 12:12 light/dark cycle with food and water available ad libitum. This research was approved by the University of Wisconsin Institutional Animal Care and Use Committee.

\section{Behavioral testing}

Behavioral tests were performed under dim red light approximately $1-2 \mathrm{~h}$ after the beginning of the dark phase of the light cycle. Each behavior was recorded and then analyzed by a trained technician blind to all treatments using The Observer ${ }^{\circledR}$ (Noldus Information Technologies) or Stopwatch + (Center for Behavioral Neuroscience, Atlanta, GA).

\section{Social play behavior}

The play behavior paradigm and scoring criteria were adapted from previous studies $[19,20]$ which both use the focal observation method to capture a "snapshot" of the play occurring in each home cage. On PN25-29, play behavior was digitally recorded in two 4-min sessions per day in the home cage covered with a clear plastic lid. One play session was $2 \mathrm{~h}$ after the beginning of the dark period and one play session was $4 \mathrm{~h}$ after the beginning of the dark session. Therefore, we recorded 8-min of play occurring in each home cage every day for five days, for $40 \mathrm{~min}$ total. There were 5-6 animals in each cage, randomly numbered and coded by tail marks. An observer blind to the treatment groups scored the recordings for the following individual behaviors: pin, pounce, bite, and chase. The frequency of each play behavior was calculated

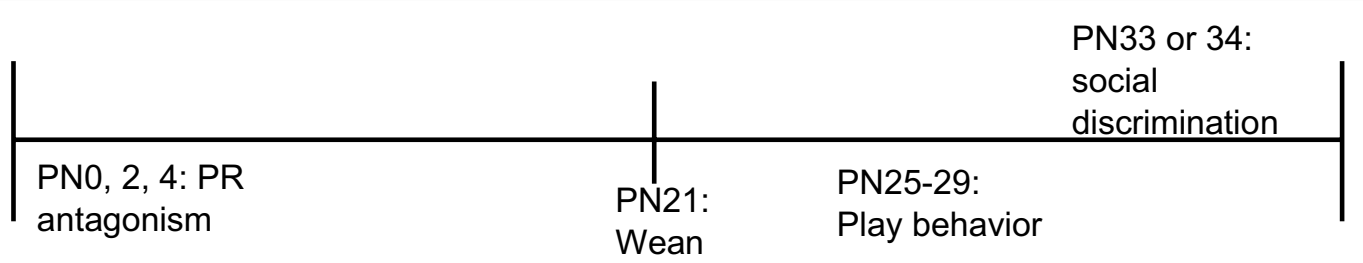

Fig. 1 Experimental overview. Male and female rats were injected with the PR antagonist CDB or vehicle control on PNO, 2, and 4 then weaned into mixed-sex cages of 5-6 on PN21. Play behavior was observed in the home cage from PN25-29 and social discrimination was measured on PN33 or PN34 
by summing each animal's play behaviors over the entire observation time. While there are different methods used to analyze play behavior, frequency of play behaviors is the most common [21]. The animals from one cage were not used in the final analysis because this cage contained animals of two different ages and social play changes with age [22,23]. Animal numbers for play behavior were therefore 12 CDB-treated females, 11 oil-treated females, 12 CDB-treated males, and 11 oil-treated males).

\section{Social discrimination}

On PN33 or PN34, rats were tested for social discrimination. Although it is typical to isolate adult animals for 1-10 days prior to testing $[17,24,25]$, we isolated the juvenile animals for only $4 \mathrm{~h}$ in this study, as social isolation is considered a severe stressor for juvenile animals [26]. In trial 1, an age and sex-matched juvenile stimulus rat was placed in the home cage of the experimental animal and the experimental animal was allowed to freely investigate for five minutes. After five minutes, the stimulus juvenile was removed and the experimental animal was alone in its cage for $30 \mathrm{~min}$. After this $30-\mathrm{min}$ intertrial interval, the stimulus juvenile from trial 1 and a stimulus novel juvenile were placed in the experimental animal's cage, and the experimental animal was again free to investigate for five minutes. The juvenile stimulus rats were distinguishable by unique tail marks drawn with permanent marker. Investigation of the stimulus juveniles was scored two ways: (1) body investigations, which included direct contact between the nose of the experimental animal and the body of the stimulus juvenile; and (2) anogenital investigations, which included direct contact between the nose of the experimental animal and the anogenital region of the stimulus juvenile. Percent novel investigation was calculated by dividing the time spent investigating the novel animal divided by the time spent investigating either animal, multiplied by 100 . Percentages greater than $50 \%$ indicate discrimination and larger scores indicate better discrimination. Animal numbers for social discrimination were $13 \mathrm{CDB}$-treated females, 12 oil-treated females, 13 CDB-treated males, and 14 oiltreated males.

\section{Statistical analyses}

All statistical comparisons were carried out using SPSS v. 28 (IMB). Statistical comparisons were carried out using a two-way ANOVA and simple main effects were conducted to examine pairwise comparisons of the effect of treatment within each sex. Partial eta squared $\left(\mathrm{N}^{2}\right)$ was used to estimate effect size, with $\mathrm{N}^{2}=0.06$ indicating a medium effect size and $\mathrm{N}^{2}=0.14$ indicating a large effect size [27].

\section{Results \\ Social play behavior}

There was no main effect of $\operatorname{sex}[\mathrm{F}(1,47)=3.1, p=0.09$, $\left.\mathrm{N}^{2}=0.07\right]$ or treatment $\mathrm{F}(1,47)=0.52, p=0.48, \mathrm{~N}^{2}=0.01$ on the initiation of play behavior; however, the interaction between sex approached significance $[F(1,47)=3.9$, $p=0.05, \mathrm{~N}^{2}=0.08$, Fig. 2A]. Simple main effects indicate that the effect of $\mathrm{CDB}$ in females approached significance $(p=0.06)$, while there was no effect of CDB in males $(p=0.37)$. There was a main effect of $\operatorname{sex}[F(1,47)=5.4$; $\left.p=0.03, \mathrm{~N}^{2}=0.11\right]$ on pins, while the main effect of treatment $\left[F(1,47)=3.3 ; p=0.08, \mathrm{~N}^{2}=0.07\right]$ and interaction between sex and treatment $[F(1,47)=2.8, p=0.09$,

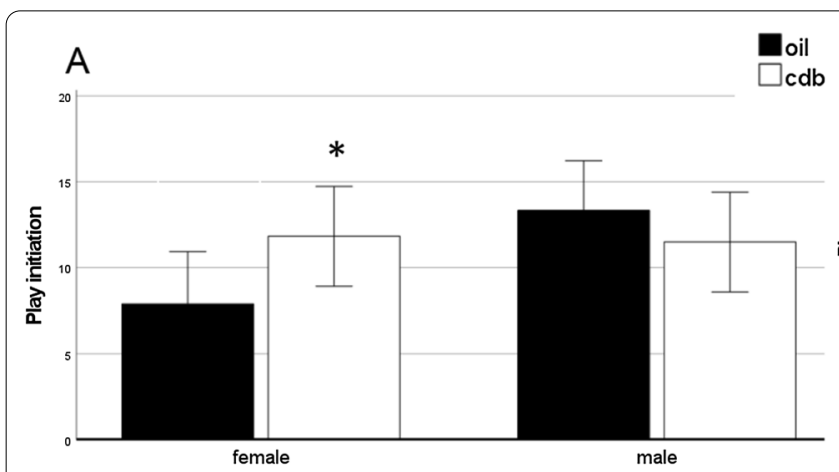

sex

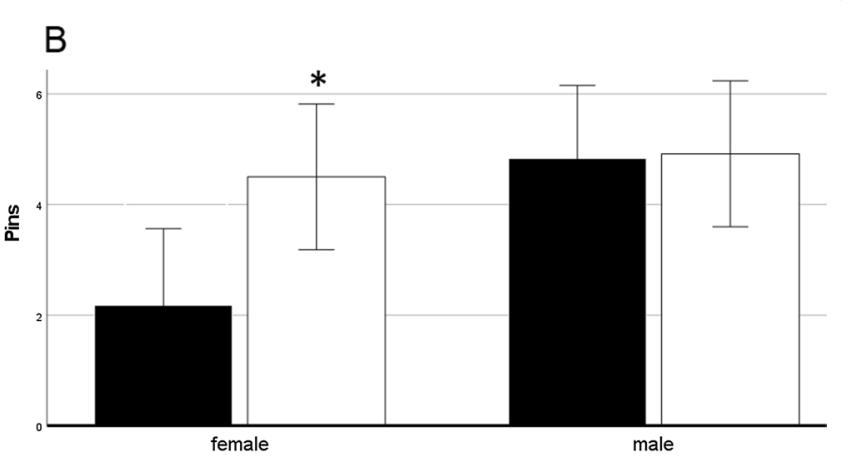

sex

Fig. 2 Social play in juvenile rats injected with CDB or control vehicle on PN0, 2, and 4. Each bar represents the mean total number of instances of play. Error bars represent $2 \times$ SEM. A The interaction between sex and CDB treatment on play initiation approached significance $\left(p=0.05, N^{2}=0.08\right)$. Simple main effects indicate that the effect of CDB in females approached significance ${ }^{*} p=0.06$ ), while there was no effect of CDB in males $(p=0.37)$. B There was a main effect of $\operatorname{sex}\left(p=0.03, \mathrm{~N}^{2}=0.11\right)$, while the main effect of treatment $\left(p=0.08, \mathrm{~N}^{2}=0.07\right)$ and interaction between sex and treatment $\left(p=0.09, N^{2}=0.06\right)$ approached significance $\left(p=0.05, N^{2}=0.08\right)$. Simple main effects indicate CDB-treated females pinned more than control females ( $\left.{ }^{*} p=0.02\right)$, while there was no effect of CDB in males $(p=0.93)$ 
$\left.\mathrm{N}^{2}=0.06\right]$ approached significance (Fig. 2B). Simple main effects indicate CDB-treated females pinned more than control females $(p=0.02)$, while there was no effect of CDB in males $(p=0.93)$. There were no main effects or interactions on pounces or chases (Table 1). Bites were observed only several times total, so these were not analyzed independently.

Frequency of play parameters (mean \pm standard error).

\section{Social discrimination}

There was no effect of $\operatorname{sex}[F(1,50)=0.47 ; p=0.50]$ or treatment $[F(1,50)=2.5 ; p=0.12]$ on percent novel anogenital investigations (Fig. 3A) and no effect of sex $[F(1,50)=0.36 ; p=0.42]$ or treatment $[F(1,50)=1.1$; $p=0.75$ ] on percent novel body investigations (Fig. 3B).

\section{Discussion}

In the present study, males initiated play more than females and exhibited more pins, which is consistent with much of the previous literature using focal observation $[19,21,28]$. Additionally, the interaction between sex and treatment approached significance. Specifically, it appears that neonatal PR antagonism increased play initiation and pins in females, with no effect in males. Interestingly, there were no sex or treatment effects on chases or pounces, suggesting that the increase in play initiation in CDB-treated females is driven primarily by increases in pins. The reason for this is unclear, but it is particularly interesting given that pinning may be indicative of dominance [21, 29]. These results are also consistent with a recent study demonstrating a sex difference in pins and total play, but not chases, in both mixed-sex and same-sex pairs [30]. On the other hand, there was no effect on social discrimination following neonatal PR antagonism.

As antagonizing PRs during early life increases pins and play initiation in females, PR signaling may play a role in organizing female social play behavior. Even though levels of PRs in the developing female brain are lower than levels in the developing male brain, their action may be important for preventing masculinization in females. That is, during the first week of postnatal life, PRs appear to be important for establishing female-typical levels of play. Although previous data have demonstrated that PRs regulate social behavior in adults $[17,25]$, the present study is the first to show effects on juvenile social play behavior following a transient neonatal manipulation of PRs. Effect sizes for all reported statistics are in the medium-large range.

Table 1 Total frequency of play behaviors from PN25-29, recorded for 8 min per day (40 min total) in the home cage

\begin{tabular}{lclcr}
\hline Play parameter & Control males & Control females & CDB males & CDB females \\
\hline Pounces & $7.6 \pm 1.0$ & $5.5 \pm 0.9$ & $6.2 \pm 2$ & $6.5 \pm 0.9$ \\
Pins & $4.8 \pm 0.7$ & $2.2 \pm 0.5^{\text {a }}$ & $4.9 \pm 0.6$ & $4.5 \pm 0.9$ \\
Chases & $0.9 \pm 0.3$ & $0.3 \pm 0.2$ & $0.4 \pm 0.2$ & $0.7 \pm 0.2$ \\
Initiation & $13.3 \pm 1.7$ & $7.9 \pm 1.5^{\text {a }}$ & $11.5 \pm 1.2$ & $11.8 \pm 1.6$ \\
\hline
\end{tabular}

There were no effects of sex or treatment on chases or pounces

${ }^{a}$ Control females exhibited fewer pins and total initiation behaviors compared to CDB-treated females, as shown in Fig. 2

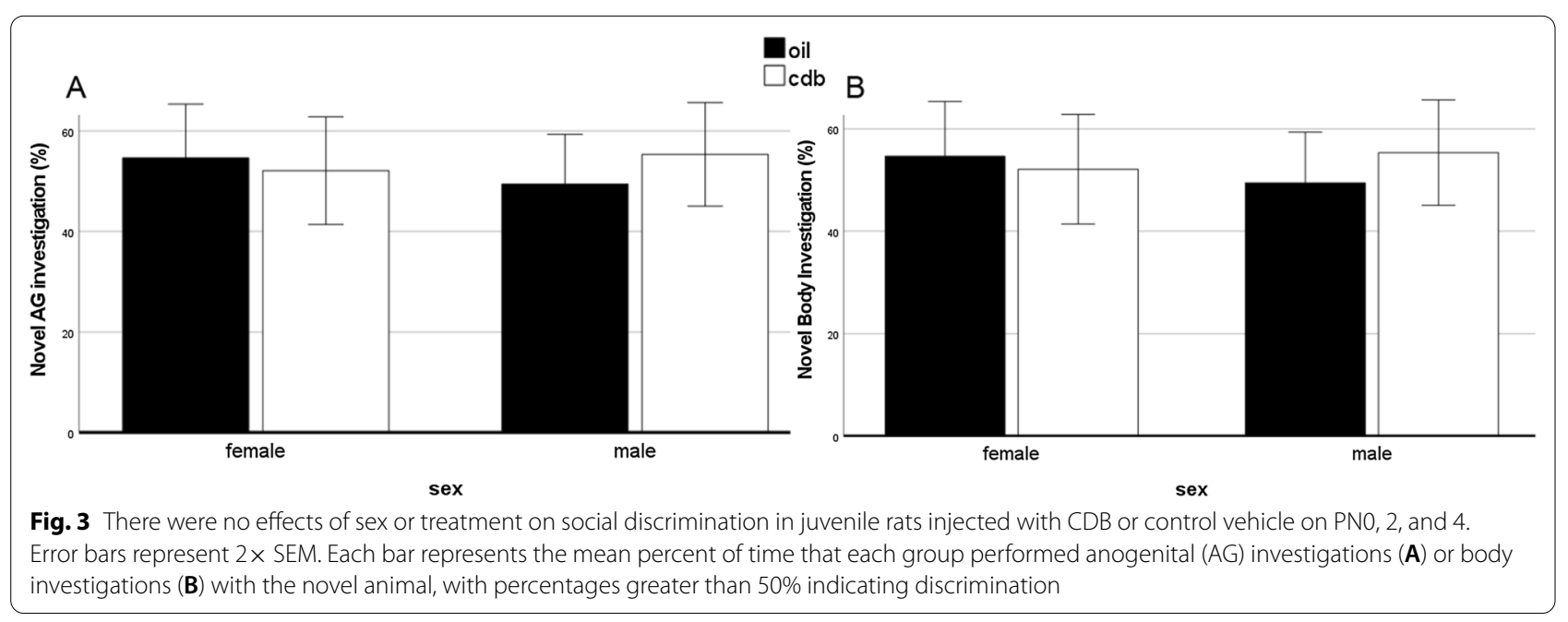


The mechanism for the increase in play in females following neonatal manipulation of PRs is unclear, as little is known about the role of PRs in the developing postnatal female brain. Manipulation of PRs may affect a variety of signaling molecules, such as arginine vasopressin, opioids, endocannabinoids, dopamine, norepinephrine, serotonin, and GABA, which are all involved in social play behavior [31-33]. Prior studies have found an increase in arginine vasopressin expression in the lateral habenula of PR knockout mice [34], but it is unclear if these effects are due to altered PRs in development or adulthood. Further studies are necessary to elucidate the relationship between PRs and juvenile social play.

In the present study, there was no effect on social discrimination following neonatal PR antagonism. Although previous data have demonstrated that PRs regulate social discrimination in adult male rats [17, 25], the present data suggest that PRs do not play an organizational role in this behavior during the first week of postnatal life. It should be noted that social discrimination is a complex behavior, and several other signaling molecules have been shown to play a role in social discrimination, including oxytocin [35-37] and arginine vasopressin [24, 38-40].

To my knowledge, the present study is the first to examine the specific role of PRs during early development on juvenile social behaviors. In females, there was an increase in play initiation, while there was no effect in males. Future studies should examine the role of neonatal PRs on the neurobiology of the brain and behavior in both juvenile and adult animals.

\section{Abbreviations}

PR: Progestin receptor; PN: Postnatal.

\section{Acknowledgements}

Thank you to Catherine Auger, Anthony Auger, and Alice Walker for the help in the design and implementation of this study, and to Jingyi Chi, Amelia Cuarenta, Heather Jessen, Megan Seibel, and Hannah White for technical assistance. Thanks to Julia Meyers-Manor for feedback on the manuscript.

\section{Authors' contributions}

RFL analyzed and interpreted all data; and wrote and revised the manuscript. The author read and approved the final manuscript.

\section{Funding}

This research was funded by National Science Foundation (NSF) Grant IOS1122074 to Catherine Auger.

\section{Availability of data and materials}

The datasets used and/or analysed during the current study are available from the corresponding author on reasonable request.

\section{Declarations}

Ethics approval and consent to participate

Not applicable.

Consent for publication

Not applicable.

\section{Competing interests}

The author declares that they have no competing interests.

Received: 22 June 2021 Accepted: 25 October 2021

Published online: 05 November 2021

\section{References}

1. MacLusky NJ, Naftolin F. Sexual differentiation of the central nervous system. Science. 1981;211(4488):1294-303.

2. González-Orozco JC, Camacho-Arroyo I. Progesterone actions during central nervous system development. Front Neurosci. 2019. https://doi. org/10.3389/fnins.2019.00503/full.

3. Morel Y, Roucher F, Plotton I, Goursaud C, Tardy V, Mallet D. Evolution of steroids during pregnancy: maternal, placental and fetal synthesis. Annales D'endocrinologie. 2016;77(2):82-9.

4. Nguyen PN, Billiards SS, Walker DW, Hirst JJ. Changes in 5alpha-pregnane steroids and neurosteroidogenic enzyme expression in the perinatal sheep. Pediatr Res. 2003;53(6):956-64.

5. Weisz J, Ward IL. Plasma testosterone and progesterone titers of pregnant rats, their male and female fetuses, and neonatal offspring. Endocrinology. 1980;106(1):306-16.

6. Wagner CK. Progesterone receptors and neural development: a gap between bench and bedside? Endocrinology. 2008;149(6):2743-9.

7. Quadros PS, Pfau JL, Wagner CK. Distribution of progesterone receptor immunoreactivity in the fetal and neonatal rat forebrain. J Comp Neurol. 2007;504(1):42-56.

8. Quadros PS, Pfau JL, Goldstein AYN, De Vries GJ, Wagner CK. Sex differences in progesterone receptor expression: a potential mechanism for estradiol-mediated sexual differentiation. Endocrinology. 2002;143(10):3727-39.

9. Wagner CK, Nakayama AY, De Vries GJ. Potential role of maternal progesterone in the sexual differentiation of the brain. Endocrinology. 1998;139(8):3658-61.

10. Forbes-Lorman R, Auger AP, Auger CJ. Neonatal RU-486 (mifepristone) exposure increases androgen receptor immunoreactivity and sexual behavior in male rats. Brain Res. 2014;16(1543):143-50.

11. Desroziers E, Brock O, Bakker J. Potential contribution of progesterone receptors to the development of sexual behavior in male and female mice. Horm Behav. 2017;1(90):31-8.

12. Willing J, Wagner CK. Progesterone receptor expression in the developing mesocortical dopamine pathway: importance for complex cognitive behavior in adulthood. NEN. 2016;103(3-4):207-22.

13. Attardi BJ, Burgenson J, Hild SA, Reel JR, Blye RP. CDB- 4124 and its putative monodemethylated metabolite, CDB-4453, are potent antiprogestins with reduced antiglucocorticoid activity: in vitro comparison to mifepristone and CDB-2914. Mol Cell Endocrinol. 2002;188(1-2):111-23.

14. Beckley EH, Scibelli AC, Finn DA. Progesterone receptor antagonist CDB-4124 increases depression-like behavior in mice without affecting locomotor ability. Psychoneuroendocrinology. 2011;36(6):824-33.

15. Birke LI, Sadler D. Progestin-induced changes in play behaviour of the prepubertal rat. Physiol Behav. 1983;30(3):341-7.

16. Birke LI, Sadler D. Modification of juvenile play and other social behaviour in the rat by neonatal progestins: further studies. Physiol Behav. 1984;33(2):217-9.

17. Bychowski ME, Auger CJ. Progesterone impairs social recognition in male rats. Horm Behav. 2012;61(4):598-604.

18. Kavaliers M, Bishnoi IR, Ossenkopp K-P, Choleris E. Differential effects of progesterone on social recognition and the avoidance of pathogen threat by female mice. Horm Behav. 2021;127: 104873.

19. Kurian JR, Bychowski ME, Forbes-Lorman RM, Auger CJ, Auger AP. Mecp2 organizes juvenile social behavior in a sex-specific manner. J Neurosci. 2008;28(28):7137-42

20. Meaney MJ, McEwen BS. Testosterone implants into the amygdala during the neonatal period masculinize the social play of juvenile female rats. Brain Res. 1986;398(2):324-8.

21. Argue KJ, McCarthy MM. Utilization of same- vs. mixed-sex dyads impacts the observation of sex differences in juvenile social play behavior. Curr Neurobiol. 2015;6(1):17-23. 
22. Pellis SM, Pellis VC. Differential rates of attack, defense, and counterattack during the developmental decrease in play fighting by male and female rats. Dev Psychobiol. 1990;23(3):215-31.

23. Thor $\mathrm{DH}$, Holloway WR. Social play in juvenile rats: a decade of methodological and experimental research. Neurosci Biobehav Rev. 1984;8(4):455-64.

24. Bielsky IF, Hu S-B, Ren X, Terwilliger EF, Young LJ. The V1a vasopressin receptor is necessary and sufficient for normal social recognition: a gene replacement study. Neuron. 2005:47(4):503-13.

25. Bychowski ME, Mena JD, Auger CJ. Vasopressin infusion into the lateral septum of adult male rats rescues progesterone induced impairment in social recognition. Neuroscience. 2013;29:52-8.

26. Mumtaz F, Khan MI, Zubair M, Dehpour AR. Neurobiology and consequences of social isolation stress in animal model-a comprehensive review. Biomed Pharmacother. 2018;105:1205-22.

27. Cohen J. Statistical power analysis for the behavioral sciences. Hillsdale: L. Erlbaum Associates; 1988.

28. Jessen HM, Kolodkin MH, Bychowski ME, Auger CJ, Auger AP. The nuclear receptor corepressor has organizational effects within the developing amygdala on juvenile social play and anxiety-like behavior. Endocrinology. 2010;151(3):1212-20.

29. Panksepp J. The ontogeny of play in rats. Dev Psychobiol. 1981;14(4):327-32.

30. Argue KJ, McCarthy MM. Characterization of juvenile play in rats: importance of sex of self and sex of partner. Biol Sex Differ. 2015;6(1):16.

31. Auger AP, Olesen KM. Brain sex differences and the organization of juvenile social play behavior. J Neuroendocrinol. 2009;21(6):519-25.

32. Trezza V, Baarendse PJJ, Vanderschuren LJMJ. The pleasures of play: pharmacological insights into social reward mechanisms. Trends Pharmacol Sci. 2010;31(10):463-9.
33. Vanderschuren LJ, Niesink RJ, Van Ree JM. The neurobiology of social play behavior in rats. Neurosci Biobehav Rev. 1997;21(3):309-26.

34. Rood BD, Murray EK, Laroche J, Yang MK, Blaustein JD, De Vries GJ. Absence of progestin receptors alters distribution of vasopressin fibers but not sexual differentiation of vasopressin system in mice. Neuroscience. 2008;154(3):911-21.

35. Engelmann $M$, Ebner $K$, Wotjak $C T$, Landgraf $R$. Endogenous oxytocin is involved in short-term olfactory memory in female rats. Behav Brain Res. 1998;90(1):89-94.

36. Ferguson JN, Aldag JM, Insel TR, Young LJ. Oxytocin in the medial amygdala is essential for social recognition in the mouse. J Neurosci. 2001;21(20):8278-85.

37. Ferguson JN, Young LJ, Hearn EF, Matzuk MM, Insel TR, Winslow JT. Social amnesia in mice lacking the oxytocin gene. Nat Genet. 2000;25(3):284-8.

38. Bluthe RM, Schoenen J, Dantzer R. Androgen-dependent vasopressinergic neurons are involved in social recognition in rats. Brain Res. 1990;519(1-2):150-7.

39. Bluthé RM, Gheusi G, Dantzer R. Gonadal steroids influence the involvement of arginine vasopressin in social recognition in mice. Psychoneuroendocrinology. 1993;18(4):323-35.

40. Dantzer R, Koob GF, Bluthé R-M, le Moal M. Septal vasopressin modulates social memory in male rats. Brain Res. 1988;457(1):143-7.

\section{Publisher's Note}

Springer Nature remains neutral with regard to jurisdictional claims in published maps and institutional affiliations.
Ready to submit your research? Choose BMC and benefit from:

- fast, convenient online submission

- thorough peer review by experienced researchers in your field

- rapid publication on acceptance

- support for research data, including large and complex data types

- gold Open Access which fosters wider collaboration and increased citations

- maximum visibility for your research: over $100 \mathrm{M}$ website views per year

At $\mathrm{BMC}$, research is always in progress.

Learn more biomedcentral.com/submissions 